\title{
Estudo dos anti-inflamatórios e analgésicos utilizados pelos idosos da Estratégia Saúde da Família de Porto Alegre
}

\author{
Autora: Luísa Scheer Elya \\ Orientadores: Fernanda Bueno Morrone ${ }^{b}$, Geraldo Attilio De Carlic \\ Data da defesa: $27 / 08 / 2014$
}

a Doutora em Gerontologia Biomédica.
b Doutora em Ciências Biológicas.

" Doutor em Farmácia e Bioquímica.

\begin{abstract}
RESUMO
Introdução: A alta prevalência de uso de anti-inflamatórios e analgésicos por idosos é amplamente discutida na literatura devido aos riscos de efeitos adversos, iatrogenias e interações medicamentosas, uma vez que a maioria dos idosos é polimedicada. A dor é um dos principais motivos de uso desses medicamentos, principalmente devido ao alto índice de artrose, artrite e reumatismo nessa população. A prescrição de anti-inflamatórios e analgésicos em idosos deve ser individualizada, pois a farmacocinética e a farmacodinâmica desses fármacos sofrem alterações no organismo idoso, podendo causar inúmeros efeitos adversos. Apesar de todos esses indicativos, muitos estudos vêm apontando uma possível ação antioxidante dos anti-inflamatórios. A literatura tem sugerido que os anti-inflamatórios induzem à geração de espécies reativas de oxigênio, contudo outros estudos demonstram que também podem desempenhar uma atividade antioxidante. Objetivo: Estudar o uso de anti-inflamatórios e analgésicos pelos idosos que frequentam a Estratégia Saúde da Família (ESF) de Porto Alegre, Rio Grande do Sul, Brasil. Métodos: Estudo transversal coletado em uma amostra aleatória de idosos da ESF do município de Porto Alegre. Este estudo faz parte do "Estudo epidemiológico e clínico dos idosos atendidos pela Estratégia Saúde da Família do município de Porto Alegre (EMI-SUS)", realizado durante o período de março de 2011 a dezembro de 2012. A coleta de dados foi realizada pelos Agentes Comunitários de Saúde, em visita domiciliar, por meio de questionário geral contendo dados sociodemográficos, condições de saúde, doenças crônicas e hábitos de vida dos idosos e uso de medicamentos. Para este estudo, foram incluídos os anti-inflamatórios e analgésicos conforme o sistema de classificação Anatomical Therapeutic Chemical. Foram coletados dados antropométricos dos idosos e para este estudo foi utilizado o índice de massa corporal (IMC). A coleta de sangue foi realizada posteriormente pela equipe do projeto na unidade de saúde onde os idosos estavam cadastrados. Foram determinados os níveis plasmáticos de marcadores oxidativos e inflamatórios, tais como insulina, HOMA-IR (homeostatic model assessmentinsulin resistance), malondialdeído (MDA), habilidade de redução férrica plasmática ou "poder antioxidante" (FRAP), produto avançado da oxidação proteica (AOPP), interleucina-6 (IL-6) e proteína c reativa ultrassensível (PCR-US). Resultados: Foram incluídos 758 idosos, com idade de 50 à 111 anos e a prevalência de uso de anti-inflamatórios e analgésicos foi de 28,8\%. O paracetamol $(67,9 \%)$ e o ibuprofeno $(31,7 \%)$ foram os medicamentos mais utilizados. O sexo feminino utilizava com maior frequência anti-inflamatórios e analgésicos $(P=0,022)$. Diante das variáveis de saúde, a autopercepção de saúde mostrou estar relacionada com o uso de anti-inflamatórios e analgésicos, sendo que, quanto pior a saúde relatada, maior o uso da terapêutica $(P<0,001)$. Entre as patologias descritas pelos idosos, a doença hepática $(P=0,004)$ e a artrose/artrite/reumatismo $(P<0,001)$ mostraram estar associadas ao uso de anti-inflamatórios e analgésicos. Foi observado que, quanto maior o uso de medicamentos em geral, maior o uso de anti-inflamatórios e analgésicos $(P<0,001)$. Quanto ao uso crônico de anti-inflamatórios não esteroidais (AINEs), verificou-se associação com as doenças gastrintestinais relatadas pelos idosos $(P=0,042)$. Quanto à associação dos AINEs com os marcadores oxidativos e inflamatórios, nada estatisticamente significativo foi encontrado. Conclusão: Os resultados deste estudo mostram a utilização moderada de anti-inflamatórios e analgésicos pelos idosos da ESF de Porto Alegre. Sabe-se da importância desses medicamentos para o manejo da dor e da inflamação, podendo interferir na melhoria da qualidade de vida do idoso. Porém, a prescrição de anti-inflamatórios e analgésicos deve ser feita com muita cautela e de forma individualizada nos idosos. Quanto aos marcadores inflamatórios e oxidativos, é importante ressaltar que os efeitos fisiológicos dos AINEs nos marcadores do metabolismo oxidativo e inflamatório ainda são escassos e controversos. Entretanto, este é o primeiro estudo que demonstrou a ausência de associação do uso de AINEs com níveis plasmáticos de marcadores inflamatórios e oxidativos, poder antioxidante e HOMA-IR.
\end{abstract}

DESCRITORES: Idoso; Anti-inflamatórios; Analgésicos; Reações adversas relacionados a medicamentos; Marcadores biológicos; Antioxidantes. 


\section{Study of anti-inflammatory and analgesic drugs used by elderly patients at the Family Health Strategy in Porto Alegre}

\section{ABSTRACT}

Background: The high prevalence of anti-inflammatory and analgesic drug use by the elderly has been widely discussed in the literature because polymedication increases the risk of adverse effects and iatrogenic and drug interactions. Anti-inflammatory and analgesic drugs are primarily used to treat pain in the elderly, who are subject to high rates of arthrosis, arthritis and rheumatism. The prescription of anti-inflammatories and analgesics in the elderly should be individualized because the pharmacokinetics and pharmacodynamics of these drugs are altered in the elderly, which can cause numerous adverse effects. However, many studies have indicated a possible antioxidant action of anti-inflammatory drugs. Some studies have suggested that anti-inflammatory drugs induce the generation of reactive oxygen species, while other studies have demonstrated that they also have antioxidant activity. Aims: We report the findings of a transversal study of the use of anti-inflammatory and analgesic drugs among a random sample of elderly patients at the Family Health Strategy (FHS) in Porto Alegre, Rio Grande do Sul, Brazil. Methods: This study is part of the "The multidimensional study of the elderly in the Family Health Strategy in Porto Alegre, Brazil (EMI-SUS)" conducted over the period of March 2011 to December 2012. Data collection was performed by community health workers at the subjects' homes using a general questionnaire and included sociodemographic data, life conditions and habits, chronic diseases and drug use. For this study, the focus was on drugs classified as anti-inflammatory or analgesic drugs according to the Anatomical Therapeutic Chemical classification system recommended by the World Health Organization. Blood was subsequently collected by the project team at the healthcare unit where the elderly patients were registered. The plasma levels of oxidative and inflammatory markers such as insulin, homeostatic model assessmentinsulin resistance (HOMA-IR), malondialdehyde (MDA), ferric reducing ability of plasma (FRAP), advanced oxidation protein products (AOPP), interleukin-6 (IL-6) and ultra-sensitivity C-reactive protein (PCR_US) were determined. Anthropometric data were measured, but only body mass index (BMI) was used in this study. Results: Among the 758 elderly patients included in this study, between 60 and 111 years old, with the prevalence of anti-inflammatory and analgesic drug use was 28.8\%. Paracetamol (67.9\%) and ibuprofen (31.7\%) were the most commonly used drugs. Women used anti-inflammatory and analgesic drugs $(P=0.022)$ more frequently than men. Self-rated health was related to the use of anti-inflammatory and analgesic drugs, i.e., the worse the reported health, the greater the use of these drugs $(P<0.001)$. Of the conditions described by the elderly, hepatic disease $(P=0.004)$ and arthrosis/arthritis/ rheumatism were associated with the use of anti-inflammatory and analgesic drugs. In addition, we observed that the higher the usage of medicines in general, the greater the use of anti-inflammatory and analgesic drugs ( $\mathrm{P}<0.001)$. Gastric problems reported by this elderly cohort may be associated with chronic or occasional use of NSAIDs $(P=0.042)$. There was no statistically significant association between the use of NSAIDs and oxidative or inflammatory markers. Conclusion: This study demonstrates the moderate use of anti-inflammatory and analgesic drugs by elderly patients at the FHS in Porto Alegre. Although these medications are important for the management of pain and inflammation, they may interfere with the improvement of the quality of life of the elderly. Thus, anti-inflammatory and analgesic drugs should be prescribed very carefully and individually in the elderly. With regard to inflammatory and oxidative markers, it is important to emphasize that the physiological effects of NSAIDs on markers of inflammation and oxidative metabolism are poorly characterized and controversial. This is the first study to demonstrate a lack of association between NSAID use and plasma levels of oxidative, antioxidant and inflammatory markers or the HOMA-IR value.

KEYWORDS: Aged; Anti-inflammatory; Analgesics; Drug-related side effects and adverse reactions; Biological markers; Antioxidants. 